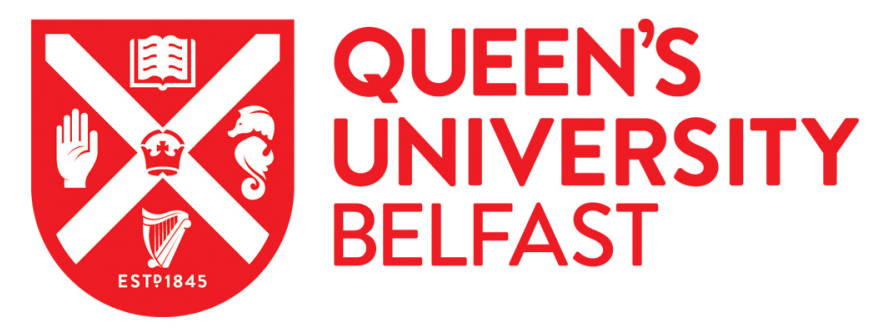

\title{
Living in The Matrix: Virtual Reality Systems and Hyperspatial Representation in Architecture
}

Kacmaz Erk, G. (2016). Living in The Matrix: Virtual Reality Systems and Hyperspatial Representation in Architecture. The International Journal of New Media, Technology and the Arts, 13-25.

\section{Published in:}

The International Journal of New Media, Technology and the Arts

Document Version:

Publisher's PDF, also known as Version of record

Queen's University Belfast - Research Portal:

Link to publication record in Queen's University Belfast Research Portal

\author{
Publisher rights \\ (C) 2016 Gul Kacmaz Erk. Available under the terms and conditions of \\ the Creative Commons Attribution-NonCommercial-NoDerivatives 4.0 \\ International Public License (CC BY-NC-ND 4.0). The use of this \\ material is permitted for non-commercial use provided the creator(s) \\ and publisher receive attribution. No derivatives of this version are \\ permitted. Official terms of this public license apply as indicated here: \\ https://creativecommons.org/licenses/by-nc-nd/4.0/legalcode
}

\section{General rights}

Copyright for the publications made accessible via the Queen's University Belfast Research Portal is retained by the author(s) and / or other copyright owners and it is a condition of accessing these publications that users recognise and abide by the legal requirements associated with these rights.

Take down policy

The Research Portal is Queen's institutional repository that provides access to Queen's research output. Every effort has been made to ensure that content in the Research Portal does not infringe any person's rights, or applicable UK laws. If you discover content in the Research Portal that you believe breaches copyright or violates any law, please contact openaccess@qub.ac.uk. 
The International Journal of

\section{New Media, Technology, \\ and the Arts}

Living in the Matrix

Virtual Reality Systems and Hyperspatial

Representation in Architecture

GUL KACMAZ ERK 


\section{EDITOR}

Barbara Formis, University Paris I, France

\section{MANAGING EDITOR}

Jeremy Boehme, Common Ground Publishing, USA

\section{ADVISORY BOARD}

Caroline Archer, UK Type, Birmingham, UK

Mark Bauerlein, Emory University, Atlanta, USA

Tressa Berman, Institute for Inter-Cultural Practices, USA

Judy Chicago, Artist and Author, New York City

Nina Czegledy, Concordia University, Montreal, Canada

Will Garrett-Petts, Thompson Rivers University, Canada

Jennifer Herd, Griffith University, Australia

Gerald McMaster, Art Gallery of Ontario, Canada

Mario Minichiello, The University of Newcastle, Australia

Attila Nemes, Kitchen Budapest, Hungary

Susan Potts, Institute of Cultural Capital, UK

Daniela Reimann, Karlsruhe Institute of Technology, Germany

Arthur Sabatini, Arizona State University, USA

Peter Sellars, University of California, USA

Ella Shohat, New York University, USA

Marianne Wagner-Simon, Freies Museum, Germany

\section{ASSOCIATE EDITORS}

Articles published in TThe International Journal of New Media, Technology and the Arts are peer reviewed by scholars who are active participants of The Arts in Society Knowledge Community or a thematically related Knowledge Community. Reviewers are acknowledged as Associate Editors in the corresponding volume of the journal. For a full list, of past and current Associate Editors please visit

THE INTERNATIONAL JOURNAL OF

NEW MEDIA, TECHNOLOGY AND THE ARTS

http://artsinsociety.com

ISSN: 2326-9987 (Print)

ISSN: 2327-1787 (Online)

http://doi.org/10.18848/2326-9987/CGP (Journal)

First published by Common Ground Research Networks in 2016 University of Illinois Research Park

2001 South First Street, Suite 202

Champaign, IL 61820 USA

$\mathrm{Ph}:+1-217-328-0405$

http://cgnetworks.org

The International Journal of New Media, Technology and the Arts is a peer-reviewed, scholarly journal.

\section{COPYRIGHT}

(C) 2016 (individual papers), the author(s)

(C) 2016 (selection and editorial matter)

Common Ground Research Networks

\section{(이요우}

Some Rights Reserved.

Public Licensed Material: Available under the terms and conditions of the Creative Commons Attribution-NonCommercial-NoDerivatives 4.0 International Public License (CC BY-NC-ND 4.0). The use of this material is permitted for non-commercial use provided the creator(s) and publisher receive attribution. No derivatives of this version are permitted. Official terms of this public license apply as indicated here: https://creativecommons.org/licenses/by-nc-nd/4.0/legalcode

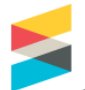

\section{Crossref}

Common Ground Research Networks, a member of Crossref www.artsinsociety.com/journals/editors.

\section{ARTICLE SUBMISSION}

The International Journal of New Media, Technology and the Arts publishes quarterly (March, June, September, December). Please visit www.artsinsociety.com/journals/call-for-papers to find out more about the submission process.

\section{ABSTRACTING AND INDEXING}

For a full list of databases in which this journal is indexed, please visit www.artsinsociety.com/journals/collection.

\section{KNOWLEDGE COMMUNITY MEMBERSHIP}

Authors in The International Journal of New Media, Technology and the Arts are members of The Arts in Society Knowledge Community or a thematically related Knowledge Community. Members receive access to journal content. To find out more, visit www.artsinsociety.com/about/become-a-member.

\section{SUBSCRIPTIONS}

The International Journal of New Media, Technology and the Arts is available in electronic and print formats. Subscribe to gain access to content from the current year and the entire backlist.

Contact us at cg-support@commongroundpublishing.com.

\section{ORDERING}

Single articles and issues are available from the journal bookstore at www.ija.cgpublisher.com.

\section{HYBRID OPEN ACCESS}

The International Journal of New Media, Technology and the Arts is Hybrid Open Access, meaning authors can choose to make their articles open access. This allows their work to reach an even wider audience, broadening the dissemination of their research. To find out more, please visit www.artsinsociety.com/journals/hybrid-open-access.

\section{DISCLAIMER}

The authors, editors, and publisher will not accept any legal responsibility for any errors or omissions that may have been made in this publication. The publisher makes no warranty, express or implied, with respect to the material contained herein. 


\title{
Living in the Matrix: Virtual Reality Systems and Hyperspatial Representation in Architecture
}

\begin{abstract}
Gul Kacmaz Erk, Queen’s University Belfast, UK
Abstract: In the digital age, the hyperspace of virtual reality systems stands out as a new spatial concept creating a parallel realm to "real" space. Virtual reality influences one's experience of and interaction with architectural space. This "otherworld" brings up the criticism of the existing conception of space, time and body. Hyperspaces are relatively new to designers but not to filmmakers. Their cinematic representations help the comprehension of the outcomes of these new spaces. Visualisation of futuristic ideas on the big screen turns film into a medium for spatial experimentation. Creating a possible future, The Matrix (The Wachowskis 1999) takes the concept of hyperspace to a level not-yet-realised but imagined. With a critical gaze at the existing norms of architecture, the film creates new horizons in terms of space. In this context, this study introduces science fiction cinema as a discussion medium to understand the potentials of virtual reality systems for the architecture of the twenty-first century. As a "role model," cinema helps to better understand technological and spatial shifts. It acts as a vehicle for going beyond the spatial theories and designs of the twentieth century and for defining the conception of space in contemporary architecture.
\end{abstract}

Keywords: Virtual Reality Systems, Hyperspace, Architectural Space, The Matrix, Science Fiction Cinema

\section{Introduction}

$\mathrm{T}$

This study is about virtual reality (VR) systems, the hyperspace of VR environments and its relation to architectural space, and a science fiction film, The Matrix, which depicts a technologically advanced hyperspace. The research introduces science fiction (SF) cinema as a discussion medium to explore the potentials of virtual reality systems for the architecture of the twenty-first century. Presently, the hyperspace of VR systems stands out as a new spatial concept creating a parallel realm to "real" space. It can be argued that virtual reality influences one's interaction with and experience of architectural space. This "otherworld" brings up the questioning of the existing conception of space, time and body. As a "role model," cinema helps to better understand such technological and spatial shifts.

This study refers to digitally supported spaces (DSS) to go beyond the spatial theories and designs of the twentieth century and to define the conception of space in contemporary architecture. These are cyberspace, hyperspace, and exospace, which are outcomes of the developments in computer science and digital technologies in less than hundred years. Compared to the history of architecture, which is almost as long as the history of humanity, this is relatively a short period of time. However, the changes in the discipline in the last century, it is possible to say, are more than the changes that took place in several. The traditional understanding of spacemaking is being transformed through scientific developments as well as their everyday applications.

A trio of concepts, reality, virtuality and virtual reality, is significant in the discussion of DSS. Architectural space and exospace (a space in outerspace) are real spaces, cyberspace (the space on the internet) is a virtual space, and hyperspace (the space in a VR system) is a virtual real space. The word "virtual" originates from virtus in Latin, meaning potential or force; "the word "virtual" is often meant to signify the absence of existence, whereas "reality" implies a material embodiment, a tangible presence" (Lévy 1998, 23). For Proust, the virtual is "real without being actual, ideal without being abstract" (Rajchman 1998, 116).

According to Jean Baudrillard, a representation is about the real whereas the virtual does not have a reference to reality as such. It is perceived though it is not there. The real implies a presence, whereas the virtual is about the absence of the real. It is about the absence of a

The International Journal of New Media, Technology and the Arts

Volume 11, Issue 4, 2016, www.artsinsociety.com

(c) Common Ground, Gul Kacmaz Erk, Some Rights Reserved, (CC BY-NC-ND 4.0)

Permissions: support@cgnetworks.org

ISSN: 2326-9987 (Print), ISSN: 2327-1787 (Online) 
reference, about what one does not have. He believes representation shows the meaning or the concept of the real whereas the virtual is a representation with no reference to something real. The distinctions between the representation and the represented vanish in the digital age. The virtual has its own reality (Baudrillard 2001, 268). Simulation, Baudrillard's 1980s-concept for the TV culture, morphs into the concept of virtuality for the personal computer (PC) culture of the 1990s. "Simulation is no longer that of a territory, a referential being, or a substance. It is the generation by models of a real without origin or reality" (Baudrillard 1994, 1). Baudrillard states (2001, 268) "relationship between the concept and reality...has broken down under pressure from a gigantic technical and mental simulation, to be replaced by an autonomy of the virtual, henceforth liberated from the real, and a simultaneous autonomy of the real which we see functioning on its own account in a demented -that is, infinitely self-referential- perspective."

Merriam-Webster defines "virtual" in computing as "not physically existing as such but made by software to appear to do so." Information technology (IT) and consulting company IBM starts using the term in the late 1960s to refer to the nonphysical links between processes or machines such as virtual memory (Pimentel and Teixeira 1995, 417). Digital virtuality is interactive. Sitting in front of a computer is different from sitting in front of a radio or television. For the latter, one has the freedom to choose the programme to watch or listen to; however, after that moment the process is one-way, from the machine towards the person. In the case of the computer, the multi-purpose machine does nothing until one starts using it. It can become a typewriter (a word processor), photo album, map, telephone, game, canvas, newspaper, radio, television, cinema, bank, or supermarket. The user chooses what to do and how to do it. The interaction between a person and the machine gives meaning to the existence of the computer. Through this interactive experience, virtuality becomes part of one's life and activities. He/she not only perceives (sees, hears, reads) virtually but also creates virtually.

The term virtual will fulfill its function when advanced VR systems become available and affordable; we are at the dawn of this era. VR may even be the total work of art of the future, the dream of artists, musicians, architects, and filmmakers: "As it evolves its art form, VR will have certain advantages over Wagner's "total work of art"” (Heim 1993, 127). Pimentel and Teixeira claim, "virtual reality might create a completely new category of art -a nonmaterial, interactive art form of the mind" (1995, xxiv). Richard Brath defines reality and virtual reality as follows (1991, 63): "The physical material world that is perceived through the senses is reality...Virtual reality is a computer-generated spatial simulation of reality, that is, it is an inhabitable alternate environment created entirely within computers. This virtual reality could be a simulation of reality, created to perceptually mimic the real world... or it could be an alternate reality, created as an entirely new environment, with its own rules, laws, and logic."

Hyperspace is a digitally supported graphic or semi-graphic space simulated partly or fully by virtual reality hardware and software. It is a space extending beyond Euclidean geometry. In hyperspace, the user gets reactions to his/her actions in real-time, and there is a sense of immersion. Baudrillard uses the term in Simulacra and Simulation to refer to a space without a referent, an origin or atmosphere behind: "The real is produced from miniaturized cells, matrices, and memory banks, models of control -and it can be reproduced an indefinite number of times from these...In fact, it is no longer really the real, because no imaginary envelops it anymore. It is a hyperreal, produced from a radiating synthesis of combinatory models in a hyperspace without atmosphere" (Baudrillard 1994, 2).

A detailed analysis of these concepts seems inevitable to better understand the technological and spatial shift of the digital age and to turn science fiction dystopias into utopias. In this context, this study focuses on the relationship between real and virtual spaces created using architecture and virtual reality systems. The aim is to find clues about the new conception and meaning of contemporary space via the concept of hyperspace in reality and in fiction. 


\section{Virtual Reality Systems}

Reality is mostly given. Virtual reality is creatable.

— Steward Brand (Pimentel and Teixeira 1995, 41)

Imagine yourself going to work in the morning. Your office is simple with white surfaces, a desk, and chairs. That is actually all, except the goggles and gloves. You put them on and run the software. As it connects you to the internet that you work and communicate through, the system "decorates" your room. Now you experience it with the images added. You have your favorite paintings on the sky blue walls. The shelves are full of books. Family photos are on your desk. You can smell the flowers on the coffee table, and feel the softness of the carpet on the floor. The music is just right for a Monday morning. For someone who enters your office, you sit in an almost empty room. Or, you may choose to have some "fake" decorations for your visitor as well; it is up to you. ${ }^{l}$

While concepts like "virtual" and "cyberspace" become almost common terms, virtual reality has been a less familiar concept until recently. Jaron Lanier ${ }^{2}$ coined the term in the mid1980 s, around the same time with William Gibson's cyberspace. "Virtual reality is a humancomputer interface in which the computer creates a three-dimensional, sensory-immersing environment that interactively responds to and is controlled by the behavior of the user" (Pimentel and Teixeira 1995, 19). A VR system responds to user actions, generates real-time three-dimensional (3-D) graphics, and creates a sense of immersion (Ibid., 11). Immersion gives the user the sense of being present in a virtual world. The feeling of being transported to a new place, telepresence, is achieved. It is an interactive as well as immersive system. There is an interaction between the user and the system. "Virtual reality is the place where humans and computers make contact" (Ibid., 17). The computer changes the viewpoint and the spatial perspective as the observer moves in it. It constantly updates the information for real-time sensation.

The first step to omit screens in computation, the design of a head mounted display (HMD) connected to a computer, is taken by Ivan Sutherland in the mid-1960s. This first monoscopic headset displays a floating green wire-frame cube in front of the user who sees this hyperreal object superimposed to real space. This is, as Baudrillard says, "the mutation of the real into the hyperreal" (1994, 30). In 1970, Sutherland completes the first fully functional stereoscopic HMD that becomes the model for the following systems. "Sutherland's dream was to place an observer in the midst of a dynamic computer-generated graphic space and, furthermore, allow the observer to move around and within this real-time perception" (Porter 1997, 138).

The first flight simulation experiments with HMD start in the late 1970s. Thomas Furness designs an effective but expensive system: a helmet that blocks the real world and renders detailed images in high resolution quickly. Michael McGreevy, following this design, develops the first practical HMD system for NASA in the mid-1980s. Scott Fisher adds audio equipment and VPL's data glove to this system to control virtual objects (see footnote 2). Both Furness' and McGreevy's systems isolate the user from reality.

By the end of the 1980s, the project turns into the Virtual Interface Environment Workstation (VIEW) used for telerobotic tasks. Through the feedback of a robot in outerspace, an operator on Earth immersed in the hyperspace of the VIEW can see and control real objects as if the arm of the robot is the arm of the operator. Scientists achieve a true virtual real medium and telepresence when the screen disappears, and the computer becomes invisible. The HMD for the eyes and the ears merges with the computer. HMD may or may not cut off the user's audiovisual sensation of the real space.

\footnotetext{
${ }^{1}$ A discussion with Digital Media Design students at the University of Pennsylvania in 2001 inspired this office fantasy.

${ }^{2}$ Lanier is a founder of VPL (Visual Programming Languages) Inc., one of the first companies that developed VR products. In the 1980s, VPL designed the first DataGloves, EyePhones, DataSuits and a shared VR system.
} 
Engineers have a great deal to improve in the existing VR systems. Myron Krueger admits "the more complete our experience of the virtual world, the more real it will seem and the more effective it will be for all purposes" $(1996,140)$. Virtual reality systems are crucial for outerspace studies, aviation, robotics, medicine, and even architecture. ${ }^{3}$ Their popularity fades towards the end of the twentieth century but they are back as currently, top IT companies are in a race to invest in VR hardware and software. When advanced, VR systems will be vital in everyday life from education (learning by doing) and social media to immersive online gaming and shopping. As Sutherland says, "A display connected to a digital computer gives us a chance to gain familiarity with concepts not realisable in the physical world. It is a looking glass into a mathematical wonderland" (Pimentel and Teixeira 1995, 43). There may not be a Star Trek Holodeck available in this decade, but at least "the visions of Sutherland and Engelbart were realized; ... the user was now inside the computer" (Ibid., 44).

\section{Alternatives and Characteristics of Hyperspace in VR Systems}

Just as the alphabet and printing press changed the way people thought, virtual reality will shape our notions of community, self, space, and time.

- Ken Pimentel and Kevin Teixeira $(1995,338)$

Cyberspace is interactive but one cannot exist in it, or participate in its processes. Unlike cyberspace, one can experience the hyperspace of a VR system. The observer is in a computergenerated environment. His/her hand lifts the simulated glass on the table and his/her eyes see another perspective of the virtual room when he/she turns around. The relationship is immersive and direct compared to the one in cyberspace. For that reason, virtual real environments are closer to architecture in terms of space. That explains the distinction between hyperspace and cyberspace in this study, unlike the approach of Gibson and others. For architects, the two imply very different spaces: "Virtual reality is very physical. I won't just see changing images on a flat screen; I will have the feeling of occupying those images with my entire body. I will enter a graphic, three-dimensional, computer-constructed world that does not look real but feels real" (Franck 1995, 20). However, a virtual real world will be quite different from reality (Ibid.):

Experiences of gravity, density, mass, weight, long distance, and the cumbersomeness of matter are absent [in VR]. The objects we see or create and the spaces we occupy in virtual worlds have very different visual and kinesthetic qualities from those in the physical world. Objects/spaces can appear, disappear, occupy the same location, and change appearance instantaneously. We can move very quickly and in all different ways. There is both a fluidity and speed of movement that are more akin to dreams than waking life. If we are "free" it is because we feel liberated from our relationship to the physical world, from the constraints and limitations that the physical world and physical matter exert upon us.

\footnotetext{
${ }^{3}$ Widely used drafting software AutoCAD is an outcome of programmer John Walker's computer-aided design ideas that benefit from VR systems of NASA and VPL.
} 
Table 1. Spatial Concepts for Alternative Hyperspaces

\begin{tabular}{|c|c|c|c|c|}
\hline & CONCEPT & & & \\
\hline \multirow[t]{6}{*}{ SPACE } & & $\begin{array}{l}\text { Architectural } \\
\text { Space }\end{array}$ & $\begin{array}{l}\text { Hyperspace } 1 \\
\text { (Office Fantasy) }\end{array}$ & $\begin{array}{l}\text { Hyperspace } 2 \\
\text { (The Matrix) }\end{array}$ \\
\hline & $\begin{array}{r}\text { Reality/Virtuality of } \\
\text { Space/Body }\end{array}$ & $\begin{array}{l}\text { Real Space } \\
\text { Real Body }\end{array}$ & $\begin{array}{c}\text { Real + Virtual Space } \\
\text { Real Body }\end{array}$ & $\begin{array}{l}\text { Virtual Space } \\
\text { Virtual Body }\end{array}$ \\
\hline & (Im)Materiality of Space/Body & $\begin{array}{l}\text { Material Space } \\
\text { Material Body }\end{array}$ & $\begin{array}{c}\text { Material+Immaterial } \\
\text { Space } \\
\text { Material Body }\end{array}$ & $\begin{array}{l}\text { Immaterial Space } \\
\text { Immaterial Body }\end{array}$ \\
\hline & (Dis)Continuous Space/Time & $\begin{array}{l}\text { Continuous Space } \\
\text { Continuous Time }\end{array}$ & $\begin{array}{l}\text { Discontinuous Space } \\
\text { Discontinuous Time }\end{array}$ & $\begin{array}{r}\text { Discontinuous Space } \\
\text { Discontinuous Time }\end{array}$ \\
\hline & Mobile/Static Space & Static Space & Mobile Space & Mobile Space \\
\hline & Introverted/Extraverted Space & Extraverted Space & Extraverted Space & Introverted Space \\
\hline
\end{tabular}

\section{Real/Virtual Space}

There are two different versions of hyperspace as described in the table above. A virtual reality system can be either both real and virtual simultaneously, or totally virtual where the sensation of the real world is blocked. In the first alternative, the virtual aspects are superimposed onto physical space. The real body is in this space. The real part of the space may turn into a simple container forming background surfaces. So the physical part of the space is simplified to become minimal as proposed in the "office fantasy." The user perceives the real and virtual parts of the space simultaneously as in Sutherland's HMD. In the second alternative, on the other hand, everything is virtual. Observers are isolated from the real world as in Furness' HMD. They are in a virtual space. They are not really -physically- there. They exist in one place while being in another. In this system, the observer turns into a virtual person who "exists" in a virtual body, an avatar. People, namely their digital incarnations, break free from their ties of gravity, enclosure, continuity, and time. ${ }^{4}$

\section{(Im)Materiality of Space and Body}

The first type of hyperspace has both material and immaterial parts whereas the second type is totally immaterial. Through immateriality, a new kind of spatial interaction and immersion is created in hyperspace. Not only space but also spatial relationships, actions and bodies are designed: "What a challenge to architects of virtual reality: not only are spaces and objects to be designed but so are all bodily relationships to them and to other bodies" (Franck 1995, 20-21). The "hyperbody" designed for a VR system may be an alternative to one's real body. Lanier's DataSuit creates such a hyperbody and brings the entire body into the simulation. The user chooses one of the designed 3-D images as an avatar, even an octopus instead of a humanoid. "What if we thus said at no time can we ever be quite sure what our bodies can yet do,... the spatial arrangements into which they might enter" (Rajchman 1998, 1). As Eric Gullichsen and Randy Walser claim "there is no need to move about in a body like the one you possess in physical reality. You may feel more comfortable, at first with a body like your "own" but as you conduct more of your life and affairs in cyberspace your conditioned notion of a unique and immutable body will give way to a far more liberated notion of "body" as something quite disposable and, generally, limiting" (Virilio 1995, 147).

\footnotetext{
${ }^{4}$ Currently some technology experts refer to alternative 1 as "augmented reality" and alternative 2 as "virtual reality," however this terminology is not commonly accepted yet.
} 


\section{(Dis) Continuity of Space and Time}

In a virtual real system, there is not one single design. The user may change the virtual parts of the space endlessly among the designs available as software. The user "personalises" the space. For this kind of spacemaking, designers are losing their authority as the ultimate decisionmakers. This is a three-dimensional space changing in real-time. It has the potential to change any moment. It is temporary; it is "edited." The next moment everything around the user may disappear or alter. That is, as Paul Virilio calls it, "the past-less and future-less moment of virtual reality" $(2000,128)$. Accordingly, any hyperspace has a discontinuous space and time.

\section{Mobile/Static Space}

Unlike architectural space, both space and body are mobile in VR systems creating a dynamic environment; "assume that you and everyone else wears a display that does not change your appearance if you already wear glasses, understands what you say, and can privately or publicly display the information you request. Such a device will be able to access information wherever and whenever it is needed. It will also remove the need to sit down in front of a screen to work. It will reintegrate the mind and body" (Krueger 1996, 140-41). Existing virtual reality systems may not be as advanced, however, that is where the technology is going, as mobile phones, tablets and the concept of home office show. People want to free their bodies.

\section{Introverted/Extroverted Space}

The first alternative of hyperspace that is virtuality combined with architectural space is extroverted whereas the second alternative is totally introverted; it is limited to the confines of the software. "Virtual reality is all about illusion... It's about the use of high technology to convince yourself that you're in another reality, experiencing some event that doesn't physically exist in the world in front of you" (Pimentel and Teixeira 1995, 7). The hyperspaces in the two Terminator films and Strange Days are extroverted whereas VR systems in Johnny Mnemonic, The Lawnmower Man and The Thirteenth Floor are all introverted.

\section{Science Fiction Space as a Representation of Hyperspace}

If we cannot imagine, we cannot foresee.

- Gaston Bachelard (1969, xxx)

Joan Ockman talks about the movie camera and "its capacity to "see" the world in ways unavailable to the human eye" (Lamster 2000, 172). It seems difficult to visualise new ideas or concepts, especially if they are related to an unexplored subject. Without their visual representations, it would be hard to imagine the utopian city of Antonio Sant'Elia, the scientific discoveries of Leonardo da Vinci, or the surreal metamorphoses of Maurits Cornelis Escher. Similarly, cinematic representations of digitally supported spaces help the comprehension of the concepts concerning them. Visualisation of futuristic ideas in space and time makes film an "obvious role model for spatial experimentation" (Vidler 2000, 100). Gibson declares, "the world we live in is so hopelessly weird and complex that in order to come to terms with it, you need the tools that science fiction develops" (Rutsky 1999, 115).

Filmmakers have inherited science fiction writers' enthusiasm about the unknown possibilities of science and outerspace after the invention of the film camera in 1895. They have visualised best SF examples of literature like the fiction of Jules Verne and Herbert George Wells 
in film space and time. ${ }^{5}$ Filmmakers' interest in realising futuristic dreams and nightmares starts as early as 1902 with Georges Melies's A Trip to the Moon. Utopias and dystopias are captured in film time. That may be the reason why architects do not design utopian cities anymore.

Most SF films are not as optimistic as architectural utopias about the future. In the previous century, directors fulfill their anxieties about the possibilities of a dystopian future via the moving pictures. Though usually advanced technologies (The Fifth Element, Tomorrowland, Dante 01) and futuristic cities (Metropolis, Logan's Run) are included in films, technology does not bring civilisation (Mad Max 2, The Postman) or happiness (Brazil, Twelve Monkeys) to humanity in most cases except few (Star Trek and Star Wars series). Many films are about space travel (Mission to Mars, Event Horizon), extraterrestrials (Alien series, E.T., The Abyss, Fantastic Planet), robotics (Wall-e, Short Circuit), genetics (Gattaca), ecology (Soylent Green) or the relationship between humans and the machine (2001: A Space Odyssey, Terminator series). In many films, the concept of reality and/or "being human" are questioned via aliens (Avatar, District 9), androids (Blade Runner), cyborgs (Robocop, Ghost in the Shell), avatars (Tron, Johnny Mnemonic), mutants (X-Men), artificial intelligent (AI) machines (D.A.R.Y.L., A.I.), dreams (Until the End of the World, Inception), memory (Strange Days, Brainstorm), the subconscious (Solaris), virtual existence (Total Recall, Virtuosity), advanced digital games (EXistenZ, Tron) or the future itself (Minority Report). Time as a spatial dimension is a significant aspect of the filmic representation of space. Visualisation of futuristic ideas in space and time makes film a perfect tool for spatial experimentation. Spaces represented in SF films are claustrophobic (Cube, Hypercube), controlled (1984, THX 1138, Dark City, Truman Show, The Giver), or related to a different existence created by the computer (The Thirteenth Floor, The Animatrix films, The Lawnmower Man). "SF authors will use their strange and imaginative environments as a testing ground for new ideas, considering in full the implications of any notion they propose" (Mann 2001, 6).

Via SF, one finds his/her way through the changes caused by technological innovations. $\mathrm{He} / \mathrm{she}$ is warned to prevent the unpleasant solutions of a possible technology as in George Orwell's 1984 (1949). Eric Rabkin explains the role of SF in the examination of the impacts of science and technology (Landon 1992, 159): "As our science and our technology change, and change us, the obligation of SF film is to give us always the richest artistic experience it can to explore ourselves and those changes, to question them, and to recompose our world in ever wiser "ways," as represented in the television series Black Mirror.

Contemporary science fiction is not limited to warnings about the possible impacts of science and technology. Like da Vinci's aircraft and submarine, science fiction creates ideas, hypotheses and theories, which inspire scientists, engineers and designers: "Since science fiction at its best is the literature of ideas, enormous amounts of creativity, art, and science go into the creation of those ideas as well as finding ways to give them external form" (Cadigan 2003, 12). Though SF is not a branch of science, contemporary science fiction can be considered as "fictional science" in which original and creative scientific ideas are discovered. Accordingly, "we humans tend to realize any possible technology" (Baxter 2003, 34) and the outside-the-box ideas explored in films broaden the limits of science, technology, and architecture.

Space is an important subject where different art forms and media intersect. Most forms of art are spatial, and the concept of space is produced and reproduced endlessly in different media. With a critical gaze at the existing norms of architecture, SF films create new horizons in terms of space. In this context, despite the potential of studying science fiction film space as a representation of architectural space, the case study that follows is based on the earlier discussion of hyperspace; cinema is a medium of architectural as well as technological analysis.

Hyperspaces are relatively new to designers but not to filmmakers. "The architecture of film has acted, from the beginning of this century, as a laboratory, so to speak, for the exploration of

\footnotetext{
${ }^{5}$ Science fiction literature as a genre is not much older than SF cinema. Mary Shelley's Frankenstein (1818) may be considered as the first SF novel.
} 
the built world -of architecture and the city" (Vidler 2000, 99). Now, it acts as a laboratory for the exploration of new spaces. Science fiction films extend the borders of the concept of space by creating the space of the future or of the non-existent. Depicting the future, SF is a critique of existing spatial ideas. In a world where what is imagined is realised, the spaces designed for films do not wait long to find their places in real life. With this observation in view, this study introduces science fiction cinema as a discussion medium to uncover the relationship between architectural space and hyperspace.

\section{The Matrix: Living in Hyperspace}

Virtual Reality, the next best thing to Being.

- Darrel Anderson $(2003,68)$

Imagine a person who discovers that he does not live in a real world; his whole life is a simulation. Lana and Lilly Wachowski directed The Matrix as the first film of a trilogy in $1999 .^{6}$ Creating a possible future, this SF film furthers the concept of hyperspace to a level not-yetrealised but imagined. In this section, spatial outcomes of the digital age will be discussed through The Matrix to unfold SF space as a representation of hyperspace and to understand the potential of virtual reality systems for contemporary architecture. The Terminator, Total Recall, the Lawnmower Man, Virtuosity, ExistenZ, The Thirteenth Floor, and Avatar are some of the other films on hyperspace whereas Inception, Strange Days, and Vanilla Sky uncover a different interpretation of the concept.

In The Matrix, Mr. Anderson, who works as a programmer in a software company and is a hacker with the alias Neo, finds out that the world he has been living in is not "real." Rather, he lives in the virtual real environment of a software programme developed by advanced AI machines. Humans and machines destroyed the world together at the dawn of the twenty-first century; humans blocked out sunlight to terminate the power source of the machines. Since the surface of Earth became inhabitable for organic life forms, humans left the surface to live in the underground city of Zion.

To use human bodies as a bioelectric energy source, the machines designed "fetus fields," power plants and a neural interactive computer simulation called the Matrix. Human beings are not born but grown in fields on Earth's surface by the machine city. They "live" in pods that are transparent capsule-like containers filled with thick red gel. Hundreds of pods cantilever out from power plants that are massive cylindrical towers. In each pod, there is one motionless human body, naked, bald and wired with numerous black cables. The minds that belong to the bodies in the slippery gel live in the Matrix, moving around in digital bodies. The virtual real-time of this urban simulation is 1999 whereas the real time in which computers rule the world is possibly 2199. In the Matrix, the machines recreated the temporal and spatial past, the prewar timeframe. The transition between these worlds is possible through a telephone line.

In the film, humans use twentieth-century technologies. The artificial intelligent machines, however, have continued developing. Diverse levels of "civilisation" are clearly differentiated on the big screen. Floating around the sewers, the Neb(uchadnezzar) hovercraft built in 2069 has a weathered look; it is rough, ragged, rusty, dark and wild with cables and pipes in complete chaos. The crew have shaved heads and worn out clothes; they sleep in bare cells and eat nutritious but tasteless food. In the futuristic machine world of the twenty-second century, on the other hand, intelligent high-tech "sentinels" and other machines control the fields and power plants. They

\footnotetext{
${ }^{6}$ In 2003, the sequels, The Matrix Reloaded and The Matrix Revolutions, short animation films entitled The Animatrix,

"Enter the Matrix" game, and The Matrix Comics enriched the Matrix world.

${ }^{7}$ The hyperspace in the film is actually the representation of the world by the end of the twentieth century, which is the time the film was shot.
} 
have smooth and shiny organic forms. The Matrix by itself is a complex and immersive software logged on by thousands for a lifetime. Such a design is unlikely to be simple.

Similar to the contrast of the old to the new in the real world, The Matrix city has two separate parts, the inhabited part made of glass and steel, and the archaic part where the city is not maintained and fully controlled. In the new Matrix, surfaces are polished and reflective. The cloths change into bright leathers, glossy PVCs, long black coats, dark sunglasses, and guns as accessories. For hacking into the Matrix, humans prefer the old and quiet part of the city like the Lafayette Hotel where Morpheus meets Neo because the ruins of the metropolis, the real face of the VR city Neo used to live in, belong to no one. To differentiate the old in the real world from the old in the Matrix, the Wachowskis make use of colour, blue for the underground world and green for the Matrix. Both the "encoded" Matrix on the computer screen and the "decoded" Matrix on the film screen are green in colour, reminding the audience of old PCs.

The Matrix city is not New York or the Waschowskis' hometown Chicago but Sydney. For the film, monuments and landmarks of the Australian city are blocked so that it becomes an anonymous metropolis by the end of the second millennium. For the helicopter rescue scene, landmark structures such as Sydney Opera House and Sydney Harbour Bridge are eliminated from the cityscape. Aldo Rossi's monument as the memory of the city is terminated.

The film is the glorification of the real; the Matrix is evil just because it is not real. The Matrix asks challenging questions: Who am I? Where am I? What is reality? What does it mean to be human and to be alive? What is the relationship between the mind and the body? The film touches on many themes such as self-discovery, free will, control, fate, belief, faith (in one's self), hope, love, birth and rebirth.

The references used in the film are as appealing as the themes. ""The Matrix" may not have had an original bone in its body, but it somehow made everything new again with a sense of character-driven imagination that turned this into one of the best science fiction films ever" (Schweiger 2003). The film is inspired deeply by literature: Lewis Carroll's Alice's Adventures in Wonderland (1865) and Through the Looking Glass and What Alice Found There (1871), Frank Baum's The Wonderful Wizard of Oz (1900), Philip K. Dick's work, Gibson's Neuromancer and cyberpunk fiction. The religious references merge West with East, Christianity, Gnosticism and Judaism to Buddhism, Taoism, and Hinduism. There are references from Greek and Roman mythology, politics (radicalism and anarchism); there are inspirations from science fiction, anime, martial arts, $\mathrm{Kung} \mathrm{Fu}$, action and fantasy films, and popular culture such as comics, cartoons, graphic novels, and video games. As expected, science and technology are amongst the sources: mathematics, quantum physics, computer science, IT, AI, and special effects. The film fascinates above all philosophers: "Name your philosophical ism and you can find it in the Matrix," (Irwin 2002, 1) existentialism, nihilism, Marxism, metaphysics, Jung, Socrates, and particularly Baudrillard. ${ }^{8}$

The Matrix is about the limits of time, space, body, mind and consciousness. It is a dystopia depicting a pessimistic future for humans and the machines. The film predicts that human life will be dependent on and managed by AI machines in the third millennium. It is about controlled space of a city in the digitally supported future of humanity. Confined and claustrophobic interiors like Neo's pod and the Neb support the idea of control. Accordingly, Mr. Anderson and Neo believe in and have different futures.

\section{Real/Virtual Space}

As a simulation, the Matrix looks real to convince humans but in fact, it is totally virtual as in hyperspace 2 in Table 1. It is much more advanced than the VR systems achieved in real life up until now. The Matrix seems as realistic as the actual real. In the film, the two worlds are

\footnotetext{
${ }^{8}$ For a detailed analysis on the film, and Simulacra and Simulation, see Adapting Philosophy: Jean Baudrillard and The Matrix Trilogy.
} 
separate from each other; one perceives either the real or the virtual real. The bluish atmosphere of the real world looks more natural compared to the greenish artificiality of the Matrix. Slow motion and high-speed cameras, fast camera movements, uncommon camera angles and positions, wirework for impossible actions, bright black garments, robotic movements and the monotonous accent of the agents, in matching dark suits, earphones and sunglasses even at night, add to the artificial atmosphere. Twins and triplets in identical costumes enhance the fabricated character of the "Construct." In the white void of the Construct with no walls, ceiling, and floor, the sense of space is lost. ${ }^{9}$ Like the minds of the humans in the pods, this space is empty and ready to be filled with literally anything.

Henri Lefebvre states, "we all know, or think we know, where discussions of truth, illusions, lies, and appearance-versus-reality are liable to lead" (1991, 7). The "idea of worlds within worlds" is everywhere in The Matrix (Wachowski Chat 1999). "It seems like you have been living two lives. In one life, you are Thomas A. Anderson, programme writer for a respectable software company," says Agent Smith in the interrogation scene, and continues: "The other life is lived in computers where you go by the hacker alias Neo, and are guilty of virtually every computer crime we have a law for." Throughout the film, reflections on mirrors, glasses, façades and screens are used for the same purpose. The shooting script of the film depicts scenes like: "We move into the monitor, entering the room as if the monitor was a window" (Lamm 2000, 291), or Neo "knows more about living inside a computer than outside one" (Ibid., 281). Neo's claustrophobic cubicle at the office echoes his pod in the power plant.

\section{(Im)Materiality of Space and Body}

For the Matrix city, "there is a new kind of construction engineering at work. One who retrofits existing skylines with digital facades and erects computer-generated skyscrapers" (Motter 2003, 146). The hyperspace of the Matrix is immaterial; it is devoid of materiality. Machines can load anything in the Matrix and humans do the same in the non-space of the Construct. Once one has a digital body he/she breaks free from ties to gravity, enclosure, continuity and time. No one can bend a spoon in real life but can in the Matrix simply because "there is no spoon."

The VR hardware is directly connected to the neural system and the mind travels to hyperspace without the body. In the power plants, flesh-and-blood people turn into cyborgs that are half human and half machine. The mind can "go" to an immaterial place such as the Matrix since it is immaterial itself. Descartes writes about the mind and matter duality, and the immaterial mind versus the rest of reality, which is material. The material body and immaterial mind (consciousness, intentionality) are left for an immaterial body and mind in hyperspace. The body is represented by an avatar in the Matrix. Neither this "residual self-image" nor the real body can live without the mind. A virtual experience for the mind may injure the Matrix body as well as the real body. Humans have a body and mind, and machines have hardware and software. The Matrix is a hyperspace for both humans and programmes like the oracle and the agents. Their image in the Matrix is represented with human bodies. Because of the immaterial character of the Matrix, an agent can invade the body of any avatar.

\section{(Dis) Continuity of Space and Time}

Both space and time in the Matrix are discontinuous. Humans run to go from one place to another whereas agents morph into any virtual body. They can be anywhere anytime. Humans can also jump from a training programme into the Matrix (as long as Tank loads them up). Machines can modify space any time. Déjà vu happens when space or time is altered in the Matrix. When Neo sees the same black cat passing by, the Matrix is changed to trap the humans in a derelict building.

\footnotetext{
${ }^{9}$ The spaceless space of the Construct resembles the prison in THX 1138.
} 


\section{Mobile/Static Space}

The Matrix has a mobile space; the machines can deconstruct and reconstruct the space simply by altering the code that will be perceived as a déjà vu or dream to a Matrix occupant. Dean Motter calls this mobile quality of the Matrix "the visual metaphor of kinetic architecture" (2003, 143). The virtual body is also mobile whereas the real body plugged into the Matrix is static. If the mind is freed, the avatar can take impossible actions like walking on walls or flying. The third dimension is conquered: "the third dimension is basically different from horizontal extension, as is indicated by the terms 'up' and 'down.' What is above and below has always been considered different, and in another sense than what is hidden behind the visual or intellectual horizon of the individual. The vertical axis is in fact traditionally considered the sacred dimension of space. It indicates "way" which leads to a reality 'higher' or 'lower' than our everyday world, a reality which wins or succumbs to the force of gravity" (Norberg-Schulz 1988, 31).

\section{Introverted/Extroverted Space}

The Matrix has an introverted space. The machines put humans into pods and all they experience is the software. They have no link to reality and no idea where their real bodies are. In this enclosed, limited and controlled environment, they are isolated in a virtual real environment from the rest of the world. The VR world in The Matrix is different in many ways from the virtual reality systems that are currently available. Firstly, it is much more advanced; the virtual real in the film seems as realistic as the actual real. Secondly, the two worlds in The Matrix are totally isolated from each other. One perceives the real space or the virtual real space at a time (as in hyperspace 2). Thirdly, no one is physically in the Matrix. The body stays in the real world while the mind connected to the software travels to hyperspace without "the body, itself invaded and re-shaped by technology" (Vidler 1990, 37). The mind perceives a VR body, a hologram, in hyperspace. With today's technology and VR systems, these aspects are not possible. Finally, different from existing systems, all five senses are active in the spatial system of the Matrix. In reality, as opposed to the film, an observer who stands in a room is surrounded with a hyperspace. He/she may experience the hyperspace without perceiving the room itself (hyperspace 2). Alternatively, the two spaces may be perceived at the same time, superimposed (hyperspace 1). In this context, with its bombardment of ideas and questions, The Wachowskis' The Matrix closes the twentieth century SF film history acting as a bridge to the twenty-first century of the genre.

\section{Architectural Space and Hyperspace}

To be able to take a real walk around a full-scale prelude to a building design has been the dream of many architects.

- Tom Porter $(1997,132)$

Hyperspace can have either totally virtual aspects or real and virtual aspects at the same time whereas architectural space is always real, always physical. Space and time in virtual reality are discontinuous compared to the continuity of real space. Like architectural space, hyperspace is three-dimensional and experienced in real-time. It is mobile while architectural space is static. Hyperspace is immaterial though may have material parts while architectural space always physically exists. The mobile body may enter hyperspace physically or may have a virtual appearance. Hyperspace has an introverted world, but when it is combined with real space, it becomes extroverted (hyperspace 1). It has the potential to change real space. It might even be an alternative to reality (hyperspace 2). Fisher says, "The possibilities of virtual realities, it appears, are as limitless as the possibilities of reality. They can provide a human interface that disappears 
- a doorway to other worlds" (Virilio 1995, 143). In this "otherworld," the body is limitless. The virtual, discontinuous, mobile, immaterial and introverted space of a VR system helps architects understand architectural space in an alternative way.

Each design problem is an opportunity to develop a new point of view. Buildings as the products of architecture have always been real entities. Now architects have the opportunity to design virtual real spaces; they can be the creators of hyperspace in a VR system, be it Oculus Rift (March 2016), HTC Vive (April 2016), Sony PlayStation VR, or Microsoft HoloLens. Karen Franck sees this as the ultimate design project: "to imagine and create objects, spaces, bodies, movement and all relationships among them without ever having to consider any of the more tedious human needs for heat, light, air, food, sleep or elimination. The architect is finally free of the "tyranny of function"" $(1995,22)$. Pimentel and Teixeira agree $(1995,204)$ : "Every element of a virtual world is a design decision. What colors, shapes, and sounds should you use? What effects will your choices have on the user? How do you make something appear realistic, and does that really serve your purpose? How do you structure an application when you can make it do anything you want? How do you guide users when they can do anything they want - or anything might happen?"

Virtual reality as an immersive medium is closer to reality than the (interactive) user interface of the computer. Porter asserts "in true virtual reality the user is autonomous, that is, free from predetermined paths and in complete control of every movement;... the immersive user is part of it, rather than a spectator" $(1997,152)$. Experts are not sure what virtual reality systems will bring to humanity once the headsets are used on a daily basis. As an alternative universe, it can be anything imagined, anything one can dream of. Filmmakers need to continue speculating through the medium of science fiction as Silicon Valley works it all out, preferably with the help of architects.

\section{REFERENCES}

Bachelard, Gostan. 1969. The Poetics of Space. Boston: Beacon Press.

Baudrillard, Jean. 2001. Selected Writings. Stanford, California: Stanford University Press.

Baudrillard, Jean. 1994 [1981]. Simulacra and Simulation. Ann Arbor: The University of Michigan Press.

Baxter, Stephen. 2003. "The Real Matrix." In Exploring the Matrix: Visions of the Cyber Present, edited by Karen Haber, 30-46. New York: St. Martin's Press.

Brath, Richard. 1991. "Information Architecture.” In Reality and Virtual Reality, edited by Glenn Goldman and Michael S. Zdepski, 63-70. New Jersey: Tech-Repro.

Cadigan, Pat. 2003. "Introduction." In Exploring the Matrix: Visions of the Cyber Present, edited by Karen Haber, 10-14. New York: St. Martin's Press.

Constable, Catherine. 2009. Adapting Philosophy: Jean Baudrillard and The Matrix Trilogy. Manchester and New York: Manchester University Press.

Franck, Karen A. 1995. "When I Enter Virtual Reality, What Body Will I Leave Behind." Architectural Design 65 (11-12): 20-23.

Gibson, William. 1984. Neuromancer. New York: Penguin Putnam.

Heim, Michael. 1993. The Metaphysics of Virtual Reality. Oxford, New York: Oxford University Press.

Irwin, William. 2002. The Matrix and Philosophy: Welcome to the Desert of the Real. Chicago, La Salle, Illinois: Open Court.

Krueger Myron W. 1996. "Virtual (Reality + Intelligence)." In Cognitive Technology: In Search of a Humane Interface edited by Barbara Gorayska and Jacob L. Mey, 129-143. Amsterdam: Elsevier Science.

Lamm, Spencer. 2000. The Art of the Matrix. New York: Newmarket Press. 
Landon, Brooks. 1992. The Aesthetics of Ambivalence: Rethinking Science Fiction Film in the Age of Electronic (Re)production. Westport, Connecticut, London: Greenwood.

Lefebvre, Henri. 1991 [1974]. The Production of Space. Oxford, Cambridge: Blackwell.

Lévy, Pierre. 1998. Becoming Virtual: Reality in the Digital Age. New York, London: Plenum Trade.

Mann, George. 2001. The Mammoth Encyclopedia of Science Fiction. New York : Carroll and Graf.

Motter, Dean. 2003. "Alice in Metropolis or It's All Done with Mirrors." In Exploring the Matrix: Visions of the Cyber Present, edited by Karen Haber, 136-147. New York: St. Martin's Press.

Norberg-Schulz, Christian. 1988 [1986]. Architecture: Meaning and Place. Rizzoli, New York: Electa.

Pimentel, Kevin, and Ken Teixeira. 1995. Virtual Reality: Through the New Looking Glass. New York: McGraw-Hill.

Porter, Tom. 1997. The Architect's Eye: Visualization and Depiction of Space in Architecture. Hong Kong: Dah Hua Press.

Rajchman, John. 1998. Constructions. Cambridge, London: MIT Press.

Rutsky, R. L. 1999. High Techne: Art and Technology from the Machine Aesthetic to the Posthuman. Minneapolis, London: University of Minnesota Press.

Schweiger, Daniel. 2003. "The Matrix Revolutions.” Film Threat. Accessed 18 October 2012. http://www.filmthreat.com/reviews/5134.

Vidler, Anthony. 2000. Warped Space: Art, Architecture and Anxiety in Modern Culture. Cambridge, London: The MIT Press.

Vidler, Anthony. 1990. "Homes for Cyborgs: Domestic Prostheses from Salvador Dali to Diller and Scofidio." Ottagono 96 (September): 36-55.

Virilio, Paul. 2000. The Information Bomb. London, New York: Verso.

Virilio, Paul. 1995. The Art of the Motor. Minneapolis, London: University of Minnesota Press.

Wachowski Chat. 1999. "Matrix Virtual Theater Presentation." Warner Bros. Accessed 25 October 2012. http://www.warnervideo.com/matrixevents/wachowski.html.

\section{ABOUT THE AUTHOR}

Dr. Gul Kacmaz Erk: Lecturer and Course Leader in Architecture, Queen's University Belfast, Northern Ireland, UK 
The International Journal of New Media, Technology, and the Arts is one of four thematically focused journals in the family of journals that support the Arts and Society knowledge community-its journals, book series, conference, and online community. It is a section of The International Journal of the Arts in Society.

The International Journal of New Media, Technology, and the Arts explores technologies of arts production and reproduction old and new, including photography, film, video, multimedia, and the internet. Its interests range from image making, to spatial-architectonic arts, design, and online cultures. It also explores the workings and potentials of the "creative industries" in the postindustrial or knowledge society.

As well as papers of a traditional scholarly type, this journal invites presentations of practice-including experimental forms of documentation and exegeses that can with equal validity be interrogated through a process of academic peer review. This, for instance, might take the form of a series of images representing artistic practice, together with explanatory notes that articulate this practice with other, significantly similar or different and explicitly referenced practices.

The International Journal of New Media, Technology and the Arts is a peer-reviewed scholarly journal. 